\title{
Трагедия Матери Сырой Земли («Вечера на хуторе близ Диканьки»)
}

\author{
ALESSANDRA CATTANI \\ Università degli Studi di Sassari, Facoltà di Lingue e Letterature Straniere, \\ Dipartimento di Scienze dei Linguaggi, Via Roma, 151, IT-07100 Sassari \\ E-mail: acattani@uniss.it
}

(Received: 12 June 2018; accepted: 3 September 2018)

\begin{abstract}
In Gogol's Dikan'ka stories cycle, the absence of a fundamental figure for the genre in question (the mother) is evident. Each story, in fact, features a "stepmother" or a surrogate of some sort, who turns out to be a demonic entity, if not a witch. This paper argues that for Gogol the Mother God, originally venerated as the main deity, assumes the form of Moist Mother Earth, forgotten by the modern Slavonic man as he increasingly distances himself from the collective (the "mir"). This process culminates in the Dikan'ka's tale The Terrible Revenge, in which Gogol highlights the transition from the feminine to the male principle, that is to say from the Moist Mother Earth to the apocryphal God of the Ukrainian sung epic poem ("duma"). Evenings on a Farm Near Dikan'ka tells of the dangerous path trodden by modern man, a path where he - in the empty space left by Moist Mother Earth - takes exclusively responsibility for the eponymous revenge.
\end{abstract}

Keywords: Russian literature, Gogol', Dikan'ka, Moist Mother Earth, individualism

FAUST (aufgeschreckt):

Mütter!

MEPHISTOPHELES:

Schaudert's dich?

FAUST:

Die Mütter! Mütter! - 's klingt so wunderlich! MEPHISTOPHELES:

Das ist es auch. Göttinnen, ungekannt

Euch Sterblichen, von uns nicht gern genannt.

Nach ihrer Wohnung magst in's Tiefste

schürfen;

Du selbst bist Schuld daß ihrer wir bedürfen.

(GOETHE 1832: 73)

«Вечерам на хуторе близ Диканьки» было посвящено множество фундаментальных трудов, различных по методологии и в целом составивших широкую основу гоголеведения. Цель данной работы - ввести в этот круг толкование «Вечеров на хуторе близ Диканьки», опираясь на возможности, обеспечиваемые наследием методологии четырехмерной герменевтики Вяч. Иванова, которая, по словам ее создателя, требует сочетания «низшей герме- 
невтики»... с «высшей». ${ }^{1}$ Посильно следуя методологии Вяч. Иванова, надеюсь, можно выявить, как восемь повестей, составляющих цикл «Вечеров», подспудно освещают важный по своему значению момент, который можно охарактеризовать как кризис, связанный с переходом от универсальности карнавального мира к обособлению отдельно выделившейся личности. В многогранном изображении этого перехода чувство «потери» проявилось отчетливо и решительно в редукции, ведущей мало-помалу к утрате того женского начала, которое было сущностью стародавнего понятия БогиниМатери, служившего некогда фундаментом многих культур, в том числе и культуры древних славян.

Гоголевский текст повествует, в частности, о метаморфозах женских оснований жизни, подвергающихся неизбежной диахронической трансформации, обретая образ Матери Сырой Земли. Но не только. Забегая вперед, к финалу данного исследования, подчеркну, что в конце концов в повести «Страшная месть» даст о себе знать скрытое указание на то, как подобная трансформация следует за реальным историческим процессом падения матриархата под тяжестью мужской концепции культуры. ${ }^{2}$ И наконец, повесть «Заколдованное место» явится свидетельством повержения женского элемента - Земли, становящейся бесплодной, неродящей.

«Вечера на хуторе близ Диканьки» рассматриваются, как правило, под углом зрения «гротескного реализма» (БАХТин 1975; см. также АВЕРИНцЕВ 1992, СИЛАРд 1985, ВиРОЛАЙНЕН 2005), с присущей ему карнавальной универсальностью. Нет сомнения во всепоглощающей природе карнавальности украинского мира, представленного в «Вечерах», прославляющих закрытую в своем мире общность, внутри которой ничего плохого не может случиться, только был бы целостным, без трещин и разрывов, физический и метафизический предел, охраняющий спокойствие простого казацкого мира (ЛотМАН 1993). ${ }^{3}$ Так карнавал оказывается главным действующим лицом, мощным оружием которого, смехом, ниспровергаются и подавляются демоны, ведьмы, а с ними и священнослужители, старосты, молодежь, старики. Жизнь и смерть, космос и хаос - все смешивается во всеобщем экстазе вакхического танца.

Тем не менее уже Ю. Манн указал на то, что в связи с большей частью ранних произведений Гоголя нельзя говорить о карнавале в узком смысле этого слова, так как:

Вечная обновляемость жизни, смена ее звеньев и «особей» не отменяет трагизма личной смерти, не может утешить того, кто потерял близкого и родного (МАнн 1988: 35).

${ }^{1}$ Концепция четырехмерной герменевтики Вяч. Иванова как варианта общей теории герменевтики была впервые описана Леной Силард (см. СилАРд 1993); ср. также СилАРд 2002.

${ }^{2}$ Как мы увидим, в этой повести мужское начало воплощается в борьбе старого и могущественного колдуна с новым Высшим Существом, которому Мать Земля уступила свое место: апокрифическому библейскому Богу.

${ }^{3}$ Анализ художественного пространства Гоголя в семиотическом ключе в книге Марии Виролайнен (см. ВиРОЛАЙНЕН 2007). 
И далее:

Смерть не сочетаема с жизнью, хотя бы последняя не знала никаких высоких движений и сводилась к отправлению простейших функций (МАнн 1988: 36).

Драматизм смерти отдельного человека вступает в сильнейший контраст с празднованием жизни остального мира: читатель, погруженный в эти две противоположные по духу атмосферы, чувствует себя все более вовлеченным в ужас и недоумение, которыми сопровождается явление смерти, исчезновение, утрата кого-то, кто прежде был.

Все это означает, что в гоголевском тексте принцип карнавальности, а значит, радостной универсальности вечного обновления, теряется по сравнению с индивидуальностью отдельно взятого существа, неспособного к осознанию смерти как континуума, продолжения.

Коллективное «мы» карнавала распадается на частное; гоголевская «устрашающая раздробленность жизни» угрожающе распространяется, начиная с первых страниц «Вечеров», и добираясь до более поздних творений.

В своем комментарии к картине Брюллова «Последний день Помпеи», Гоголь отмечает:

Картина Брюллова может назваться полным, всемирным созданием. В ней все заключилось. По крайней мере, она захватила в область свою столько разнородного, сколько до него никто не захватывал. Мысль ее принадлежит совершенно вкусу нашего века, который вообще, как бы сам чувствуя свое страшное раздробление, стремится совокуплять все явления в общие группы и выбирает сильные кризисы, чувствуемые целою массою (Гоголь 1952: 109).

Кажется, что здесь, как и во многих других случаях, Гоголь говорит о необходимости возврата к укладу жизни, когда интересы отдельного человека основывались на интересах социума в его целом, как и о том, что раздробленность приводит к появлению чувства вины. Эта вина несет в себе наказание, нисходящее без исключения на всех, кто запятнал себя наивысшей провинностью - удалением от социума. Несмотря на то, что этому наказанию подвергается каждый, оно имеет своей целью вновь объединить всех, дать почувствовать себя принадлежащими единому процессу.

Таким образом Гоголь обеспокоенно говорит о человечестве, коллективный дух которого, дух древнего мира, ${ }^{4}$ постепенно исчезает, уступая место культу отдельно взятого человека.

В одной из предыдущих работ мне уже приходилось отмечать важный по значению момент в «Вечерах на хуторе близ Диканьки», где, опираясь на концепцию М. Бахтина, можно проследить переход от принципа универсаль-

\footnotetext{
${ }^{4}$ Как известно, у восточных славян термин «мир» означал договор, достигнутый разными родами, живущими в общине в пределах одного поселения. Речь шла о «мире», когда существовало согласие всей общины в видении прав и традиций (см. GASPARINI 1973: 473, GARZANITI 2013: 60-68).
} 
ности и карнавальности к значению личного, единичного и романтического (Cattani 2011: 73-83; см. также Tagliagambe 1986).

Нечто подобное можно усмотреть и в истории дочерей Богини-Матери, если рассматривать процесс трансформации древнеславянского язычества под углом зрения культурно-исторической перспективы. Поначалу эти «дочери» сплочены в своем единстве и верности матери, затем они оставляют еe, отрываются, чтобы начать свой личный путь.

Как известно, культ Богини-Матери имеет древнейшие корни. Первые упоминания о нем восходят к периоду неолита, примерно к 7000 годам до нашей эры. ${ }^{5}$ В монографии Джоанны Хуббс, посвященной данному культу, проведен подробный анализ этого явления, начиная с его истоков. В ходе этого увлекательного путешествия в мир мифа становится ясным, что для воссоздания образа Богини-Матери необходимо сосредоточить внимание на множестве женских мифологических фигур, от нее в какой-то мере происходящих и ее частью являющихся. Среди них - Мать Сыра Земля, сопряженная, в свою очередь, с многочисленными существами языческого пантеона древнеславянского мира, от русалок до вил и Бабы Яги, от ткачих до амазонок, от Мок(о)ши до Рая, Пекла и Алконоста, русского женского божества персидского происхождения, полудевы-полуптицы. Мать Сыра Земля и ее культ будут господствовать на земле русской вплоть до изобретения плуга. Ее самое древнее появление, как и Богини-Матери, совпадает по датам с возникновением женских фигурок в Триполье (HuBBS 1993: 31; см. также ПОМЕРАНЦЕВА 1975: 80-82) ${ }^{6}$ и остается значимым до постепенного перехода к патриархальному устройству общества. Предполагается, что момент отдаления между гинекократической и фаллократической системами общества, последовавший за перемещением индоевропейских народов, приходится на 3500-2500 годы до н. э. ${ }^{7}$

${ }^{5}$ Связь между культами универсальной прародительницы эпох палеолита и неолита совершенно ясно документирована находками как минимум в двух местах древних раскопок: в Чатал Хююке (Анатолия) и в Триполье (недалеко от Киева, между Днепром и низовьями Дуная). В обоих местах находки свидетельствуют о переходе от охотничества к сельскому хозяйству: земля нуждается в защите и плодовитости: богиня-мать гарантирует это. В своих первичных проявлениях она предстает в отчетливо зооморфном виде, часто предпочитая животных с метаморфозными изменениями в цикле жизни: от лягушки к бабочке, от медведя, спящего зимой и вновь активного весной, к змее. С третьего тысячелетия изображение божества становится антропоморфным, представляемым как женский дух, заключенный между небом и землей, или же как «богоявление», окруженное мужскими существами, рожденными ею же (см. FEDOTOV 1960: 9-15, 344-362; см. также BILLINGTON 1966, ChODOROW 1978). В особенности в тексте Чодорова показано, как в обществе, основанном на сельском хозяйстве (ср. старославянские общества), архетип матери, хранительницы плодородия, превосходит значение отношений божества и его почитателей.

${ }^{6} \mathrm{O}$ связи между Матерью-богиней и другими божествами, как, например, лешим, см. ИвАНОВ-ТОПОРОВ 1965: 173-176.

${ }^{7}$ Первым юридическим документом, в котором официально закреплена второстепенная роль женщины, является закон царя Уруинимгина 2352/2342 до н. э. В нем, желая воссоздать порядок, заведенный на земле богами, царь запрещает вдовам снова выходить замуж, а непо- 
Радикальное изменение происходит именно в переходе от почитания женского божества к поклонению божеству мужскому. Западные славяне теперь поклоняются мужскому богу-защитнику воинов, храмы для которого возводятся не в бесконечных лесах, среди могучих деревьев, а прямо в селениях, да еще и из глиняных кирпичей. ${ }^{8}$

Мифологическая Мать Сыра Земля, тем не менее, продолжает дарить своим детям жизнь и плодородие, и в определении советских времен «Мать Россия», в компромиссном созвучии религиозного контекста и диктата исторических условий, слышатся еще отзвуки матриархата.

Киев - «мать градов русских», матушка-Москва, со своими концентричными кольцами, напоминающими объятие (совсем скоро ей будет противопоставляться «угловатый» и властный Петербург, созданный из перпендикулярных друг другу проспектов, непреклонный, холодный, выталкивающий), и «матушки» - живительные речушки, пересекающие бескрайние славянские земли, как и «Волга - мать родная», воспетая этим нарицательным именем в многочисленных народных песнях (см. Кузнецов 1947). Жизненная сила, родительница и заступница, жизнь и смерть, гостеприимная, но и карающая, и жестокая, и непримиримая. В крестьянской культуре она предстает матерью и женой царя, в культуре интеллигента преобразуется в потерянный рай, в мифический золотой век, безвозвратно утраченный. Справедливо замечание Джоанны Хуббс:

Russian literature to the present day repeats the theme of the prodigal son's return to the motherland for absolution, empowerment, and rebirth (HuBBS 1993: 231).

Итак, существует особенный по своему значению, исторически датированный период, когда в славянском мире происходит переход от матриархата к патриархату. Процесс постепенный, со свойственными ему временными и географически обусловленными особенностями. ${ }^{9} \mathrm{~B}$ «Вечерах на хуторе близ Диканьки» этот момент можно узнать особенно в переходе от Диканьки к Киеву - новому фону повести «Страшная месть», где акцентируется, в сущности, современное видение данного процесса как четкое отдаление от старой общины и приближение к фрагментирующему миру современности.

слушным и неуважительным к мужчинам назначает наказание обезображивания. Знаменитый Кодекс Хаммурапи также содержит несколько законов, регулирующих браки, положение женщины и ее сексуальные обязанности. Этот документ ляжет в основу еврейского закона, который окончательно закрепит власть мужчины над женщиной. По этой теме см. также в высшей степени ценные исследования Рафаэла Патаи об исчезновении имени богини Ашеры (сопрестольницы Ваала у хананеев и Яхве) - уже на самой ранней стадии (РАТАI 1990).

${ }^{8}$ Если исходить из трудов Прокопия Кесарийского и других византийских источников VI века, в которых содержится большое количество информации по данной теме, можно увидеть, что мужской бог уже узурпировал власть, некогда принадлежавшую Великой Матери. У западных славян, тем не менее, оба культа, мужского и женского божества, часто соприкасаются друг с другом (см. ИвАНОВ-ТоПОРОВ 1965: 30-52).

${ }^{9}$ Указанная тема достаточно обширна и нуждается в особом историческом анализе. 
А в целом своем единстве «Вечера на хуторе близ Диканьки» могут быть восприняты и как предостерегающий крик, как предупреждение всему человечеству. Страницы произведения полны ошеломляющей, потрясающей пустоты: нет «матери». В другом литературном жанре подобное отсутствие не было бы таким явным, очевидным, но здесь речь идет о народных сказаниях, о забавных шутливых историях про свадьбы и жениховство, про испытания во имя любви и радужного будущего влюбленных. И тема здесь - традиция.

Анализируя повести одну за другой, ${ }^{10}$ нельзя не заметить, как с почти лейтмотивно оформленной настойчивостью нарастает эта тема.

Уже в «Сорочинской Ярмарке» бросается в глаза, что Хивря - «мать» главной героини, - вовсе не мать ей, а мачеха. Многие детали, связанные с ней, указывают на элементы нечистой силы: таково описание ее зеленокрасного одеяния, ${ }^{11}$ почти таково и мимолетное замечание рассказчика о том, что на ее лице проскальзывало «что-то столь неприятное, столь дикое, что каждый тотчас спешил перенести встревоженный взгляд свой на веселенькое личико дочки» (ГоГоль 1940: 113), носящей выразительное имя Параска. Показательно, что спонтанно влюбившийся в Параску Грицько сразу же улавливает сущность Хиври, угрожающую ее падчерице, что выливается у него в почти по-казацки оформленное противопоставление: «Я бы отдал все свое хозяйство, чтобы поцеловать ее [Параску - А. К.]. А вот впереди и дьявол сидит!» (Гоголь 1940: 114). Таким образом, фигура мачехи выступает как разъединяющая, дьявольская сила, потерпевшая, однако, поражение: веселая свадьба, несмотря на ухищрения Хиври, состоялась, и «от одного удара смычком музыканта, в сермяжной свитке, с длинными закрученными усами, все обратилось, волею и неволею, к единству и перешло в согласие» (Гоголь 1940: 135).

Имя главного героя второй повести цикла («Вечер накануне Ивана Купала») уже само по себе многозначно: Петро Безродный. Обращает на себя внимание и то, как автор знакомит с ним читателя:

${ }^{10}$ Кажется, не лишним будет напомнить, что первая книга «Вечеров на хуторе близ Диканьки» вышла в сентябре 1831 г., вторая - годом позже, в 1836 г. и в 1842 г. книги были переизданы, а последнее прижизненное издание относится к 1852 г. Очень возможно, что первой повестью, написанной Гоголем, была «Вечер накануне Ивана Купала», в 1829 г., в своем первоначальном виде, значительно отличающемся от окончательной версии, напечатанной в 1830 году в журнале Отечественные записки. К 1829 г. относится и сборник повестей: «Сорочинская Ярмарка», «Майская ночь, или утопленница» и «Пропавшая грамота». «Заколдованное место» датируется концом 1829 - началом 1830 гг.; с 1830 по 1832 гг. была написана «Ночь перед Рождеством» с многочисленными исправлениями и дополнениями автора; «Страшная месть» была написана в 1831 г. и напечатана в 1832 г., тогда как «Иван Федорович Шпонька и его тетушка» завершает собой цикл «Вечеров» и относится к концу 1831 г.

11 Зелено-красные цвета являются типичными цветами русской народной демонологии. По мнению М. Власовой, темно-зеленый цвет - цвет демона, таким образом представленного в многочисленных рисунках и аффресках; красный цвет, цвет целого предмета одежды или какой-либо его части, например шапки или пояса, - это цвет языческого демона, лешего или водяного (см. ВЛАСОВА 1995: 340). 
В том селе был у одного козака, прозвищем Коржа, работник, которого люди звали Петром Безродным; может, оттого, что никто не помнил ни отца его, ни матери (Гоголь 1940: 140).

Стало быть, речь идет о молодом человеке не только без родителей, но и без роду, без племени, т. е. без корней. Он одинок, а потому является легкой добычей для нечистой силы. Никто не воспротивится уготованной ему трагической судьбе, никто его не защитит. Детоубийство и ужас, вызванный описанием ведьмы (в исступлении утоляющей жажду кровью невинного шестилетнего Ивася - «ангела-хранителя» бедного Петра Безродного), - это те элементы, которые заставляют пока что сомневаться в карнавальном характере этой «были, рассказанной дьячком +++ской церкви». Несмотря на то, что действие этой «были» разворачивается в широко известный карнавальный «вечер накануне Ивана Купала», речь идет об особом карнавале, где противоборствующие силы действуют с целью разрушить гармонию всеобщности и универсальности, внутри которой растворяются все страхи, страх смерти в том числе.

Особое внимание гоголеведов привлекает третья повесть - «Майская ночь, или утопленница», где рассказ о любви молодого козака Лёвко к Ганне контрапунктно соотносится с повествованием о молодой панночке из «подводного мира снов» и ее отце, о его жене-ведьме - мачехе панночки, способной превратить свою падчерицу в несчастную русалку.

Думается, следует обратить внимание и на то, что параллельно с закреплением мотива «дьявольской природы мачехи», появившегося уже в «Сорочинской ярмарке», в «Майской ночи» осторожно дает о себе знать «мотив государственной власти», постепенно вытесняющей собой установки собственно родовых традиций. В этом отношении необычайно интересна фигура отца Левко, роль которого оформлена государственной структурой России в качестве местного «Головы», детальному и иронически окрашенному описанию которого посвящена 2-я подглавка повести, где особенно примечателен раздел, повествующий о том, что

давно еще, очень давно, когда блаженной памяти великая царица Екатерина ездила в Крым, был выбран он в провожатые; целые два дня был он в этой должности и даже удостоился сидеть на козлах с царицыным кучером. И с той самой поры еще голова выучился раздумно и важно потуплять голову, гладить длинные, закрутившиеся вниз усы и кидать соколиный взгляд исподлобья. И с той поры голова, об чем бы ни заговорили с ним, всегда умеет поворотить речь на то, как он вез царицу и сидел на козлах царской кареты [курсив - А. К.] (Гоголь 1940: 161).

Название следующей подглавки подключает к вышеобозначенным мотивам еще один, не менее важный: «Неожиданный соперник. Заговор». Первой частью этого названия акцентируется проблема притязаний головы на любовь верной его сыну Ганны как очередной показатель разрушения тра- 
диций, согласно которым отец не смел попирать права своего сына и его поколения. ${ }^{12}$ Что же касается второй части этого названия («Заговор»), то ею утверждается карнавальная победа молодого поколения над «старым дурнем», развернутая в сюжете фантастически оформленным содружеством бунта парубков (очевидных авторов «приказа», подписанного «Комиссаром, отставным поручиком Деркач-Дришпановским») против притязаний Головы и помощью панночки из «подводного мира снов», закрепленная песней Левко.

Главный герой «Пропавшей грамоты» - дед. Нет у него ни семьи, ни наследников, ни предков, и нет в этой «были» ни одного материнского персонажа. Зато повествование полно ведьм. Тем не менее, появляется здесь фигура, которая в следующей повести станет центральной - это царица, которую удостоился видеть дед, посланный к ней в качестве гонца с грамотой от гетмана. Рассказом деда о ней («рифмующимся» с «мемуаром» Головы) завершается текст «Пропавшей грамоты»:

Там [в ее Петербургском дворце? - А. К.] нагляделся дед таких див, что стало ему надолго после того рассказывать... глядь - сидит сама, в золотой короне, в серой новехонькой свитке, в красных сапогах, и золотые галушки ест (Гоголь 1940: 191).

В «Ночи перед Рождеством», при кажущейся естественности ситуации, где есть сын и мать (отец даже не упоминается), обрамляющим элементом повествования становится природа с ее предрождественскими холодами, расцвеченными фольклором, а главным героем - кузнец Вакула, ${ }^{13}$ образ которого имеет яркую мифологическую окраску: с одной стороны, он - сын ведьмы, любительницы плотских удовольствий, привычной к бесовским вылазкам, а по существу - продолжательницы серии мачех с их «меркантильными» и разлагающими социум устремлениями, с другой стороны, он - «самый набожнейший из всего села человек» (Гоголь 1940: 225).

Особенно выразительной в этой повести оказывается фигура царицы, воплощающей иронически оформленный «суррогат» матери, подспудно подготовленный в предыдущих «былях» рассказами о встречах с императрицей ее верноподданными служителями: местечковым Головой («Майская ночь») и дедом - гонцом гетмана к царице («Пропавшая грамота»). Вспомним сцену в «Ночи перед Рождеством», когда - перед лицом царицы, сопровождаемой «самим Потемкиным»:

${ }^{12}$ Не случайно в повествовании подчеркивается, что Ганна помнит и о том, как она «еще была маленькою и жила у матери», и просит Левко напомнить ей рассказы о доме, где жила панночка (Гоголь 40: 156).

${ }^{13}$ В. Иванов и В. Н. Топоров усматривают в действиях кузнеца описание модели всего мира. Властелин грозы и молнии, «Кузнец» обитает на небесах и, как воплощение духа огня, противостоит водной стихии, с которой находится в вечной борьбе. В славянской мифологии с его смертью связано рождение Днепра (см. ИвАнов-Топоров 1974). Недаром в эпилоге именно «Ночи перед Рождеством» изображена единственная в «Вечерах» счастливая мать жена кузнеца Вакулы. 
Запорожцы вдруг все пали на землю и закричали в один голос: - Помилуй, мамо! помилуй! - Кузнец, не видя ничего, растянулся и сам со всем усердием на полу.

- Встаньте! - прозвучал над ними повелительный и вместе приятный голос. Некоторые из придворных засуетились и толкали запорожцев. - Не встанем, мамо! не встанем! умрем, а не встанем! - кричали запорожцы (Гоголь 1940: 236).

Кажется очевидным, что ирония Гоголя здесь легко обыгрывает тот факт, что государственная власть России претендует на роль «материнской власти», способной щедро одарить и заслуженно наказать. Настоящая мать русских людей - это Россия, а царица - ее воплощение, и запорожцы легко подключаются к организуемой государыней игре, при том, что память их переполнена разного рода прибаутками о ворах-«москалях» и чертях-немцах. Впоследствии в творчестве Гоголя этот мотив развернется и станет скрытой основой построения сюжета «Мертвых душ», как на то указала замечательная работа К. Соливетти (см. Solivetті 2012).

Особое место занимает в цикле «Вечеров» повесть «Страшная месть», следующая непосредственно за «Ночью перед Рождеством». Отличает ее, прежде всего, своеобразный стиль повествования: на смену разговорному языку рассказчиков былей и повестей, собранных в сборнике пасичником, - языку обыденному, простецкому, вместе с тем - насыщенному фольклорными реминисценциями и вполне созвучному говору диканьковских персонажей с его множеством лексико-семантических оттенков, обусловленных традициями карнавальной жизни, приходит вдруг язык возвышенный, временами эпически окрашенный, подобающий повествованиям о героических подвигах и о делах давно минувших дней, долго живущих в памяти социума. Голоса рассказчиков, увлеченно утопавших в подробностях своих «историй» о ведьмах и бесах, крадущих луну, беззвучно исчезают, уступая место голосу всеведущего повествователя. И только в конце повествования, когда Гоголь раскрывает внешний облик этого загадочного сказителя, нельзя не заметить аналогий с Гомером: ${ }^{14}$

Уже слепец кончил свою песню; уже снова стал перебирать струны; уже стал петь смешные присказки про Хому и Ерему, про Сткляра Стокозу... но старые и малые все еще не думали очнуться и долго стояли, потупив головы, раздумывая о страшном, в старину случившемся деле (Гоголь 1940: 282).

Мифопоэтическая сила произведения передается читателю с первых же страниц, размыкая защитный круг, созданный приятельской и обыденной лексикой Диканьки. Новое измерение проявляет себя чужим и тревожащим, уже готовым встретить новых персонажей гоголевской прозы следующего периода. Это будут «жертвы» Петербурга, отмеченные неотвратимым и жестоким роком, ищущие единственно возможный выход, как это ни странно,

${ }^{14}$ О связи рассказчика «Вечеров» с Гомером, уже упоминавшейся Андреем Белым, см. ВАЙСКОПФ 1993: 183. 
в безумии или смерти. Даже природа в «Страшной мести» изменилась. Будучи динамически связанной с миром человеческих действий и чувств, сочувствующей, очеловеченной, она тоже должна приспосабливаться к новому миру. Таков и Днепр:

Он не бунтует. Он, как старик, ворчит и ропчет; ему все не мило; все переменилось около него; тихо враждует он с прибережными горами, лесами, лугами и несет на них жалобу в Черное море (Гоголь 1940: 255).

Великая река была той преградой, которая изменяла пространство в ширину и в глубину, отражая в своих водах небесную высоту. Теперь весь мир, который «Вечера» называли землями по ту сторону Днепра, изменился.

Старинная река, издавна созерцая проходящую возле нее жизнь, понапрасну ворчит, не соглашаясь. Подобное описание природы романтически окрашено и близко поэзии Тютчева, хотя, как указывает М. Вайскопф, в нем сказываются здесь некоторые черты богомильства (см. ВАйскоПФ 1993: 9199). Нельзя оставлять без внимания и тот факт, что подобное описание природы вполне включается в более широкую картину гоголевской географии. $\mathrm{B}$ «Страшной мести» географическое место повествования - это уже поэтическая конструкция, внутри которой предопределяются судьбы и пути развития и целых народов, и отдельных личностей. В этом, как известно, Гоголь видит божественный замысел: ход истории и судьбы людей зависят от географического положения, которое им предопределяет Провидение. ${ }^{15} \mathrm{~B}$ финальной части повести колдун, в отчаянном бегстве, встречает на пути постоянные преграды, которыми природа, объединив все свои силы, пытается задержать виновного беглеца: древний дух вновь окреп и сводит с ним счеты:

Ему чудилось, что все со всех сторон бежало ловить его: деревья, обступивши темным лесом, и как будто живые, кивая черными бородами и вытягивая длинные ветви, силились задушить его; звезды, казалось, бежали впереди перед ним, указывая всем на грешника; сама дорога, чудилось, мчалась по следам его... (Гоголь 1940: 276).

Подобная сила сродни чему-то сверхъестественному, как раз поэтому Гоголь, немногим раньше, говорит о «невероятном чуде», которое настолько расширило горизонты, что видимыми стали все концы света, и Лиман, ${ }^{16}$ и Черное море, и целый Крым, Галиция и еще дальше, сами Карпаты. Как отличается от такого описания простая природа Диканьки! - река, лес, защитные барьеры, охраняющие «наше». Настал момент, когда природа словно бы теряет свои границы. Ничто больше не защищает потерянного и одинокого внутри бесконечного пространства. Предательски обманутая, словно обижаясь, природа гневается и наказывает. Однако в словах Гоголя мы прекрасно узнаем и ту, что подразумевается за деревьями, молниями, реками и облаками:

${ }^{15}$ О важности географического описания в произведениях Гоголя см. Синявский 1992 , Дуккон 2008, Дуккон 2011.

${ }^{16}$ То есть великое устье рек, где Днепр и Буг впадают в Черное море. 
Водяные холмы гремят, ударяясь о горы, и с блеском и стоном отбегают назад, и плачут, и заливаются вдали. Так убивается старая мать козака, выпровожая своего сына в войско. Разгульный и бодрый, едет он на вороном коне, подбоченившись и молодецки заломив шапку; а она, рыдая, бежит за ним, хватает его за стремя, ловит удила и ломает над ним руки и заливается горючими слезами (ГоГОль 1940: 269).

Такой плач природы - это плач матери, древней матери, которая, как ни ищи, в тексте больше не встретится.

Подобному изменению природы в «Вечерах» соответствует столь же радикальное изменение и в описании среды. Киев - большой город, заменивший маленькие селения и расположенный по обе стороны Днепра.

Данило Бурульбаш, его верные соратники-казаки, жена Катерина и их маленький сын приглашены на свадьбу, где произойдет появление ужасного колдуна, отца Катерины, о котором муж Катерины позднее заметит: «Не так еще страшно, что колдун, - [...] - как страшно то, что он недобрый гость» (Гоголь 1940: 247). Бесспорно главный герой повести, старый колдун и злодейский дух, представляет собой центральное звено нашего исследования. Этому гоголевскому персонажу были посвящены многочисленные труды, но для нашей работы особенно интересными представляются выводы Юрия Манна, которыми четко обозначается тот факт, что колдун прекрасно осознает свои ужасные, достойные презрения действия: убийство матери Катерины, самой Катерины и маленького внука, инцестуальная одержимость, богохульство, колдовство и так далее. Но на самом деле, как подчеркивает Ю. Манн, речь идет не столько об осознавании того, что делает отец Катерины, сколько о непонимании того, «почему он это делает». А мотивировка всех этих ужасов находится в старинном предании. Зло, исходящее от душегуба, предопределено древним законом, не допускающим исключений. Но это не делает колдуна менее отрицательным героем. Кстати, он никогда не называется по имени, потому что в гоголевской прозе использование имени собственного имеет серьезное значение. Здесь Гоголь вполне красноречив: нет в мире имени для такого ужасного злодея.

В отличие от Андрея Белого, ${ }^{17}$ Манн подходит к вопросу, опираясь на семиотически-антропологический метод, и разделяет точку зрения Лотмана, который усматривает в «Страшной мести» ядро архаичного видения мира. Однако, по мнению Манна, это творение Гоголя не исчерпывает себя в этом видении, потому что насыщенность гоголевского повествования развивается согласно непрерывной диахронической смене старого и нового, античного и современного, известных культурных моделей и еще неизведанных.

Старый колдун, в роли предустановленного судьбой преступника, вершит зло, потому что не может действовать иначе, у него нет выбора, а пото-

${ }^{17}$ Как известно, А. Белый считал центральной идеей повести экспликативную функцию мифа, воспевающего род как общность, целостность, внутри которой растворяется индивидуалистическая идея (см. БЕлый 1994, БЕлый 1934: 66-71). 
му он злодей и жертва в одном лице. В своей изолированности он всегда на стороне, противоположной канонической, он против христианства, против казачества, против жизни, весь он - противостояние. Колдун обладает почти безграничной властью: он знает будущее, разговаривает с душами, укрощает их по своему желанию, телу его незнакомы физические пределы, а время и пространство для него приобретают границы неопределенности. И это всемогущество заставляет его верить в себя больше, чем в любое другое земное или небесное существо. Он представляет собой апофеоз самоутверждения «сверхчеловека», бросающего вызов закону Божьему. Здесь особенно хотелось бы обратить внимание на эпизод, который побудил рассматривать колдуна как ключевую фигуру предлагаемого здесь размышления. Речь идет о диалоге между злодеем и душой его дочери Катерины:

- Где ты была? - спросил он, и стоявшая перед ним затрепетала. - О! зачем ты меня вызвал? - тихо простонала она. - Мне было так радостно. Я была в том самом месте, где родилась и прожила пятнадцать лет. О, как хорошо там! Как зелен и душист тот луг, где я играла в детстве: и полевые цветочки те же, и хата наша, и огород! О, как обняла меня добрая мать моя! Какая любовь у ней в очах! Она приголубливала меня, целовала в уста и щеки, расчесывала частым гребнем мою русую косу... Отец! - тут она вперила в колдуна бледные очи: - зачем ты зарезал мать мою! (Гоголь 1940: 258).

Колдун, отец-старик, одержимый инцестуальной страстью, антихрист, это он убил свою жену, мать Катерины, и остался единственным родителем в искаженном виде. Так «Страшная месть» знаменует собою финальный момент процесса, долгое время развертывавшегося на страницах предыдущих повестей в цикле «Вечеров». Необходимо, однако, указать на еще один, весьма немаловажный для завершения данного анализа факт: впервые гоголевские персонажи оказываются непосредственно перед лицом Бога.

Мир Диканьки, со всеми своими демонами и ведьмами, еще не нуждался в библейском Боге. Священнослужители в Диканьке больше напоминают смешные карикатуры, их молитвы-заклинания и символ креста - скорее знаки суеверия; дьявол для них - скорее черт, чем дьявол, ${ }^{18}$ нестрашный, забавный, вполне фольклорный персонаж.

В «Страшной мести» все меняется. Чтобы противостоять дьявольской силе не хватает ритуальных заговоров времен Диканьки. Необходимо Высшее вмешательство, превосходящее человека: Его решения человек не в состоянии избежать. Только Бог может рассудить ужасные перипетии судьбы побратимов Ивана и Петра, ставших после смерти лютыми врагами. Однако

${ }^{18}$ Черт - демоническая фигура, по большей части фольклорная, которая противопоставляется человеку и препятствует ему. Речь, однако, идет не о таком уже страшном враге: от него можно достаточно легко отделаться, благодаря многочисленным ухищрениям. Его действия могут быть зловредными, но никогда не убийственными (см. ВлАСовА 1995). По-другому воспринимается Дьявол: коварное существо, принадлежащее религиозной сфере и противопоставляющее себя самому Богу. 
не примечательно ли, что Бог, о котором повествовал слепой певец, в сущности, полностью переложил принятие решения на человека: «Великой есть грешник сей человек!... не выберу я ему скоро казни; выбери ты сам ему казнь!» (Гоголь 1940: 281). После чего Бог этой легенды со всей очевидностью оставляет человека наедине с его ответственностью за принятое им решение о наказании (и как бы «провоцируя» споры грядущих поколений касательно проблем свободы воли):

Страшна казнь, тобою выдуманная, человече! - сказал бог. Пусть будет все так, как ты сказал, но и ты сиди вечно там на коне своем, и не будет тебе царствия небесного, покамест ты будешь сидеть там на коне своем! (Гоголь 1940: 282).

Так задуманная Иваном «Страшная месть» положила начало цепи злополучных событий, которые приведут к проклятию по отношению к целому роду, обреченному на жестокие горести в мучительной вечности. И если в первых повестях «Вечеров» тот, кто забывает древнюю роль Матери, виновен в том, что уступает место ведьме-мачехе, то в «Страшной мести» тот, кто согласен выдвинуть на первое место свое решение о возмездии, перенимая тем самым прерогативу Бога, ${ }^{19}$ порождает цепь страшных событий, где, в сущности, все оказываются так или иначе виновными. Таким образом, повести цикла «Вечеров» отмечают собой тот самый «критический момент»: переход от женского начала как принципа материнской любви, к воинственному мужскому, от Матери Сырой Земли к апокрифическому библейскому Богу украинского народного эпоса - думы. ${ }^{20}$ Так закончилось эпическое повествование сказителя-бандуриста.

Фигуру «богоборца» - старого колдуна - сопровождает целый ряд персонажей.

В образе Катерины можно увидеть эпохальное изменение по отношению к миру Диканьки: перед нами образ современной жены. В отличие от женщин Диканьки, которые в переходе от невесты к жене теряют нежность и красоту, превращаясь в злобное и агрессивное по отношению к мужу-подкаблучнику существо, Катерина, напротив, предана семье, мужу, а также его желаниям.

Конечно, Катерина - мать, в сущности, единственная во всем цикле, но какова ее доля? Сначала она духовно унижена и растерзана отцом, затем физически ослаблена и, наконец, уничтожена. ${ }^{21}$ Это она виновата в том, что

${ }^{19}$ Ср.: «Мне отмщение и Аз воздам» (Рим. 12:19).

20 За информацию об этом жанре украинского фольклора сердечно благодарю О. В. Марченко и Л. В. Ушкалова.

${ }^{21}$ Необходимо отметить, что в произведениях Гоголя отсутствует отношение к женщине как носительнице вечного Женского начала, то, что вскоре уже будет пронизывать особенно поэзию символистов. Поэзия конца XIX - начала XX века рождается, как известно, на глубоком знании поэзии Данте и апофеоза «cuor gentil», продолжаясь как в глубинах, по Достоевскому, так и в торжестве особого представления о мудрости или Софии, реализующейся именно в Женском божественном начале. 
в семью проникло зло, это ее вина в том, что она, не веря отцу-колдуну, всетаки освободила его из тюрьмы, оказавшись виноватой в смерти сына и мужа. Во всей этой цепи событий нет карнавального духа обновления. И если в повестях «Вечеров» практически ни разу не описана ни одна материнская фигура, ${ }^{22}$ то почему в единственной повести, где, напротив, представлены два материнских образа (Катерины и ее матери), обе матери погибают от одного и того же демонического мужского начала? В чем смысл этого тотального истребления семьи? И в чем состоит вина смелого Бурульбаша и его маленького сына? Зачем столько гибелей?

Вернемся немного назад и снова перечитаем слова Гоголя, посвященные картине Брюллова, где писатель говорит о «сильных кризисах, чувствуемых целою массою». Смысл этих слов ведет к выводу: наказание, чтобы быть понастоящему эффективным, должно быть коллективным. Оно должно поразить индивидуума за его грехи и поразить всеобъемлюще: тогда наказание возродит в наказуемых стремление, импульс к единству с другими.

Таким образом, проклятие рода приобретает оттенок божьей кары для тех, кто отстраняется от начала начал. И если философия Шеллинга описывает напряженное сосуществование универсального и индивидуального волеизъявления, то Гоголь уже видит опасную склонность человека к личной исключительности, к ячеству, указывая на его неизбежные последствия, то есть на божью кару, суть которой, как и у древней, вечной матери - привести «все на свои места».

И Бурульбаш виновен. Горделивый до дерзости, он вынуждает своих людей и жену психологически зависеть от него. Бурульбаш готов к самопожертвованию, но - чтобы казаться еще смелее, сильнее и значительнее. Две натуры уживаются в молодом казаке. С одной стороны, для него важны сила и значение коллектива, жизнь казацкой сечи, общность и умение делиться. С другой стороны, он бессознательно стремится к собственническому, отдельному, к культу одного героя, видя и в жене дорогое ему, но зависимое он него существо «низшего ранга» - бабу. Бурульбаш является частью той массы людей, которая отдалилась от коллективного осознавания Матери Земли, и теперь, видя, как патриархальная концепция Бога отстраняет древнее женское божество, устремляется все быстрее к воинственному индивидуализму, оставаясь далеко от Бога.

В повести «Иван Федорович Шпонька и его тетушка» образ матери в очередной раз заменен, как и в ряде «бытовых повестей», суррогатом, однако совсем новым: тетушкой Ивана Шпоньки, с не менее комически (хотя и по-другому) окрашенным именем: Василиса Кашпоровна Цупчевська. Будучи родной сестрой недавно скончавшейся матери главного героя, она не упускает случая бегло насплетничать сыну на связь его матери с соседом, причину чего читатель может без труда понять, опираясь на разные замечания рассказчика, в частности, о том, что сама Василиса Кашпоровна «заму-

22 За исключением эпилога рассказа «Ночь перед Рождеством». 
жем... никогда не была, и обыкновенно говорила, что жизнь девическая для нее дороже всего. Впрочем... никто и не сватал ее» (Гоголь 1940: 293) и, особенно, нарисованный в повести ее портрет, где по-игровому смешиваются установления природы и социума, указывает на то, с каким своеобразным продуктом имеет дело читатель:

Казалось, что природа сделала непростительную ошибку, определив ей носить темнокоричневый по будням капот с мелкими сборками и красную кашемировую шаль в день светлого воскресенья и своих именин, тогда как ей более всего шли бы драгунские усы и длинные ботфорты (Гоголь 1940: 293).

Видимо, именно потому, в качестве бессознательного намека на наступившие нарушения традиций природы, в одном из писем Тетушки племяннику появляется приписка:

Чудная в огороде у нас выросла репа, больше похожа на картофель, чем на репу (ГоГОль 1940: 287).

Последовавшее затем в пятой части описание «нового замысла» решительной тетушки перерастает в рассказ о кошмарных сновидениях бедного Шпоньки, беспрестанно кишащих опасными женами - опасными именно потому, что это - жены, и напрасно Шпонька пытается от них сбежать: странные существа появляются с колоколен, из обрезков материй, вылезают из карманов штанов...

Что же стало с Матерью Сырой Землей и ее силой, некогда полной и неоспоримой? Если переход от женского начала к мужскому нашел свою высшую критическую точку в повести «Страшная месть», то в рассказе о бедном Шпоньке он приобрел комическую окраску, мотивно предвещая вместе с тем комическое изображение трагических последствий этого процесса в финальной были, рассказанной дьячком +++ской церкви.

В «Заколдованном месте» - особенно примечательно итоговое рассуждение рассказчика:

Я знаю хорошо эту землю: после того нанимали ее у батька под баштан соседние козаки. Земля славная! и урожай всегда бывал на диво; но на заколдованном месте никогда не было ничего доброго. Засеют как следует, а взойдет такое, что и разобрать нельзя: арбуз - не арбуз, тыква - не тыква, огурец - не огурец... чорт знает, что такое! (Гоголь 1940: 316).

Обиженная и забытая, оставленная на милость нечистых сил, земля умирает, теряя свое основное предназначение: плодородность. Богиня-Мать не дает больше своих древних плодов. То, что теперь исходит от нее, - это лишь странные, неопределенные, проклятые существа, слишком влюбленные в себя, чтобы заметить свою безобразность. 


\section{Литература}

АВЕРИНЦЕВ 1992 = АвЕРИНЦЕВ С. С. Бахтин, смех и христианская культура. В кн.: М. М. Бахтин как философ. Москва: «Наука», 1992. 7-19.

БАХтин 1975 = БАХтин М. М. Рабле и Гоголь. Искусство слова и народная смеховая культура. В кн.: БАХтин М. М. Вопросы литературы и эстетики. Исследования разных лет. Москва: «Художественная литература», 1975. 484-495.

БЕЛЫй 1934 = БЕЛЫй А. Мастерство Гоголя. Исследование. Ленинград-Москва: «Государственное издательство художественной литературы», 1934.

БЕлый 1994 = БЕлый А. Луг зеленый, Гоголь. В кн.: БЕЛЫй А. Символизм как миропонимание. Москва: «Республика», 1994. 328-334, 361-371.

ВАЙскОПФ 1993 = ВАЙСКОПФ М. Сюжет Гоголя. Морфология, идеология, контекст. Москва: «Радикс», 1993.

ВИРОЛАЙНЕН 2005 = ВИРОЛАЙНЕН М. Страх и смех в эстетике ГоГоля. В кн.: БУКС Н., Конт Ф. (ред.) Семиотика страха. Париж-Москва: «Европа», 2005. 124-135.

ВИРОЛАЙНЕН 2007 = ВиРОЛАЙНЕН М. Проблема границЫ в сюжетах Гоголя. В кн.: ВиРОЛАЙНЕн М. Исторические метаморфозы русской словесности. Санкт-Петербург: «Амфора», 2007. 339-349.

ВлАСОвА 1995 = ВлАСовА М. Н. Новая абевега русских суеверий. Санкт-Петербург: «Северо-Запад», 1995.

Гоголь 1940 = Гоголь Н. В. Вечера на хуторе близ Диканьки. В кн.: Гоголь Н. В. Полное собрание сочинений в 14 томах. Т. 1. Москва-Ленинград: «Издательство АН СCCР», 1940. 101-316.

Гоголь 1952 = Гоголь Н. В. Последний день Помпеи. В кн.: Гоголь Н. В. Полное собрание сочинений в 14 томах. Т. 8. Москва-Ленинград: «Издательство АН СССР», 1952. 107-114.

Дуккон 2008 = Дуккон А. Подземная география и хтонические мотивы в ранних повестях Гоголя. Studia Slavica Hung. 53 (2008): 293-304.

Дуккон 2011 = Дуккон А. Историческая легенда в романтической повести. «Страшная месть» Гоголя и легенда Степана, князя Семиградского. В кн.: Щукин В. Г. (ред.) Двести лет Гоголя. Kraków: Wydawnictwo UJ, 2011. 15-122.

Иванов-ТоПоров 1965 = Иванов В. В., ТоПорОв В. Н. Славянские языковые моделируюшие семиотические системы. Москва: «Наука», 1965.

ИвАнОВ-ТоПОРОв 1974 = ИвАнов В. В., ТоПОРов В. Н. Проблема функций кузнеца в свете семиотической типологии культур. В кн.: Материалы всесоюзного симпозиума по вторичным моделирующим системам. Т. 1. Тарту: Тартуский государственный университет, 1974. 87-90.

КУзНЕцОВ 1947 = КУзНЕцОВ Е. Из музыкального прошлого Москвы. Советская музыка 1947/5: 39.

ЛотмАН 1993 = ЛоТмАН Ю. М. Проблема художественного пространства в прозе Гоголя. В кн.: ЛотмАн Ю. М. Избранныле статьи в 3 томах. Т. 1. Таллинн: «Александра», 1993. 413-447.

МАнн 1988 = МАнн Ю. В. Поэтика Гоголя. Изд. 2-е, доп. Москва: «Художественная литература», 1988.

ПОМЕРАНЦЕВА 1975 = ПОМЕРАНЦЕВА Э. В. Мифологические персонажи в русском фольклоре. Москва: «Наука», 1975.

СиЛАРд 1985 = СилАРд Л. Карнавальное сознание / карнавализация. Russian Literature 18 (1985): 151-175. 
СилАРд 1993 = СилАРд Л. Русская герменевтика XX века. Studia Slavica Hung. 38 (1993): 173-183.

СиЛАРд 2002 = СилАРд Л. Герметизм и герменевтика. Санкт-Петербург: «Иван Лимбах», 2002.

Синявский 1992 = Синявский А. В тени Гоголя. Москва: «Старт», 1992.

Billington $1966=$ Billington J. The Icon and the Axe. An Interpretive History of Russian Culture. New York: Knopf, 1966.

CATTANi 2011 = CATTANi A. La Dikan'ka di Gogol' come cronotopo del carnevale bachtiniano. Studia Russica XXIV. Budapest, 2011. 73-83.

CHODOROW $1978=$ CHODOROW N. The Reproduction of Mothering. Psychoanalysis and the Sociology of Gender. Berkeley: University of California Press, 1978.

Fedotov $1960=$ Fedotov G. P. The Russian Religious Mind. Kievan Christianity. The 10th to 13th Centuries. New York: Harper, 1960.

GARZANITI 2013 = GARZANITI M. Gli Slavi. Storia, culture e lingue dalle origini ai nostri giorni. Roma: Carocci, 2013.

GASPARINI 1973 = GASPARINI E. Il matriarcato slavo. Antropologia culturale dei protoslavi. Firenze: Sansoni, 1973.

Goethe 1832 = Goethe J. W. Faust. Der Tragödie zweiter Teil. Stuttgart: Cotta, 1832.

Hubbs 1993 = Hubbs J. Mother Russia. The Feminine Myth in Russian Culture. Indianapolis-Bloomington: Indiana University Press, 1993.

Patai 1990 = Patai R. The Hebrew Goddess. Detroit: Wayne State University Press, 1990.

Solivetti 2012 = Solivetti C. "Tutti a Cherson!" Cartografia delle "Anime morte". In: Letteratura e Geografia. Atlanti, modelli, letture. Macerata: Quodlibet, 2012. 149-170.

TAgLiagambe 1986 = TAgLiagamBE S. L'origine dell'idea di cronotopo in Bachtin. In: Bachtin teorico del dialogo. Milano: Franco Angeli, 1986. 35-78. 